\title{
ON NET EXTERNAL ASSETS IN REGIONS AND STATES OF THE U.S.A.
}

\author{
Petr Duczynski*
}

\begin{abstract}
:
We present rough estimates of net external assets for 8 regions and 51 states of the United States. These estimates have been derived from the data on gross state product and state personal income. We identify the largest creditors and debtors and observe relatively important disparities in net external assets across the states and regions. The analysis is also focused on various trends in the indebtedness of regional economies. Using the correlation matrices for selected base years, the degree of capital mobility across regions and states is quantified. We provide some evidence that states are more open to capital flows than regions. In the end, the convergence of net external assets between 1980 and 2000 is confirmed.
\end{abstract}

Keywords: capital movements, correlation matrices, net external assets, regions and states of the U.S.A.

JEL Classification: C82, F41, R10

\section{Introduction}

Net external assets (NEA) and the current account (CA) of the balance of payments constitute fundamental macroeconomic variables. NEA measure the position of an economy on the world credit market, while CA indicates the change of this position over time. If expressed relative to GDP (the gross domestic product), NEA differ substantially across economies. Developed countries are both net lenders (Japan; Switzerland) and net debtors (Australia, Canada, the United States). Developing countries are typically net debtors. Oil exporting countries are frequently strong net creditors.

Sinn (1990) provided balance-sheet estimates of NEA and NEA/GDP for a large number of countries in 1970-1987. These estimates were the consolidated NEA of the central bank, deposit money banks, private households and firms, and public authorities. Some NEA data (the international investment position) are available from the International Financial Statistics of the International Monetary Fund. Duczynski (2000) computed rough NEA estimates for 113 countries in 1990 using the cumulated CA in 1970-1990 and also rough NEA estimates for U.S. states in 1977, 1982, 1987, and 1992 from the data on gross state product (GSP) and state personal income (SPI).

* Department of Economics, Faculty of Informatics and Management, University of Hradec Králové, Rokitanského 62, CZ - 50003 Hradec Králové (petr.duczynski@uhk.cz).

This work was partially supported by the CERGE-EI Foundation, Grant number GRC III-064, and by the Grant Agency of the Czech Republic, Grant number 402/04/0642. 
These data are presented in the Survey of Current Business and on the web site of the U.S. Department of Commerce, Bureau of Economic Analysis, http://www.bea.gov. NEA were also examined by Lane and Milesi-Ferretti (2001). They constructed estimates of external assets and liabilities for 67 industrial and developing countries. Among other things, they studied trends in NEA and shifts in debt-equity ratios over time.

It should be noted that there already exists some research on the flows of capital among U.S. states. Kalemli-Ozcan et al. (2005) study the determinants of capital flows across U.S. states. They analyse a simple neoclassical model and observe high capital mobility among the states.

The present paper discusses some aspects of NEA for 8 regions and 51 states of the United States in the 1980-2000 period. It identifies the largest creditors and debtors and tries to shed light on the trends in capital movements across the states. Using correlations of NEA for selected base years, we can provide some information concerning the degree of capital mobility among the states. We also examine the regional current account and the convergence of NEA.

\section{The Construction of Net External Assets}

This contribution presents some estimates of NEA for states and regions of the United States. A full database of annual observations for the 1977-2001 period is available in a PDF file at the Internet address http://duczynski.czweb.org, where NEA-to-GSP ratios are expressed in percentage terms. The computation of NEA uses estimates of received property income (derived from SPI) and produced property income (derived from GSP). The received property income consists of the estimate of net interest, rental income of persons, proprietors' income, and the estimate of corporate profits. SPI does not directly contain net interest, nor does it contain corporate profits. Nevertheless, SPI contains personal interest income and personal dividend income. We obtained the estimate of net interest from the personal interest income using the ratios of these variables at the U.S. level. The ratios of net interest to personal interest income at the level of the United States amounted to 0.70 in 1980, 0.64 in 1990, and 0.57 in 2000. The personal interest income exceeds the net interest: the personal interest income consists of the net interest, the interest paid by persons, and the government interest. With the given adjustment of the personal interest income to the net interest we got estimates of NEA in which the federal government debt was allocated to U.S. states.

We obtained the estimate of corporate profits from the personal dividend income (again with the use of the ratios of these variables at the U.S. level). The ratios of corporate profits to personal dividend income were 3.11 in 1980, 3.00 in 1990, and 2.10 in 2000 .

The produced property income was derived from the property-type GSP. The property-type GSP contains the depreciation of capital. Estimates of capital depreciation for individual U.S. states are not available. The ratios of the produced property income (with no depreciation) to the property-type GSP at the U.S. level amounted to 0.64 in 1980, 0.67 in 1990, and 0.65 in 2000. These ratios for corresponding years were used in the construction of the estimates of the produced property income for individual regions and states. 
The computation of NEA for individual regions and states was based on the following formula (see Duczynski, 2000):

$$
\mathrm{NEA} / \mathrm{GSP}=(\mathrm{R}-1) \mathrm{K} / \mathrm{GSP} \text {, }
$$

where $\mathrm{R}$ is the ratio of received to produced property income and $\mathrm{K}$ is the value of physical capital. We assume the same rate of return inside and outside each region and state. $\mathrm{R}$ is then the ratio of all assets to domestic physical capital. R-1 is then equal to the ratio of NEA to physical capital. The Survey of Current Business presents estimates of private physical capital (fixed reproducible tangible wealth) for the United States. We allocated physical capital to individual states in proportions to the property-type GSP. From (1) we obtained preliminary estimates of NEA/GSP. The given procedure was also applied to the United States as a whole and the resulting preliminary NEA estimates were compared to the estimates of NEA presented in the International Financial Statistics (2002). We computed differences between the NEA/GSP estimates from the International Financial Statistics and our preliminary estimates for the United States. We added the given differences to the preliminary estimates of NEA/GSP for individual regions and states. By this relatively small correction we got aggregateconsistent estimates of NEA/GSP for regions and states - the sum of NEA across states or regions should correspond to the overall position of the United States.

The final estimates of NEA/GSP for 8 regions and 51 states are presented in Table 1. Regions are denoted by boldface italics. The computation of NEA involved numerous approximations; consequently, the given estimates are only rough estimates.

Table 1

Net External Assets in Relation to Gross State Product (in \%) for Regions and States of the United States

\begin{tabular}{|c|c|c|c|c|c|}
\hline Region or state / year & 1980 & 1985 & 1990 & 1995 & 2000 \\
\hline U.S.A. & 13 & 2 & -3 & -6 & -22 \\
\hline New England & 96 & 41 & 24 & 19 & -15 \\
\hline Connecticut & 140 & 63 & 33 & 21 & -8 \\
\hline Maine & 81 & 57 & 47 & 17 & 10 \\
\hline Massachusetts & 79 & 26 & 12 & 19 & -11 \\
\hline New Hampshire & 73 & 39 & 52 & 12 & -53 \\
\hline Rhode Island & 73 & 37 & 10 & 3 & -68 \\
\hline Vermont & 100 & 73 & 43 & 56 & 33 \\
\hline Mideast & 55 & 25 & 17 & 10 & -16 \\
\hline Delaware & 39 & -38 & -69 & -66 & -115 \\
\hline District of Columbia & 6 & 0 & -26 & -25 & -28 \\
\hline Maryland & 51 & 21 & 3 & 12 & 0 \\
\hline New Jersey & 76 & 40 & 22 & 16 & -18 \\
\hline New York & 61 & 13 & 9 & 10 & -18 \\
\hline Pennsylvania & 54 & 48 & 51 & 16 & -7 \\
\hline Great Lakes & 28 & 7 & 11 & 2 & -7 \\
\hline Illinois & 33 & 21 & 19 & 12 & 8 \\
\hline Indiana & 15 & 0 & -6 & -29 & -26 \\
\hline Michigan & 55 & 11 & 36 & 29 & 3 \\
\hline
\end{tabular}




\begin{tabular}{|c|c|c|c|c|c|}
\hline Ohio & 8 & -9 & -7 & -16 & -28 \\
\hline Wisconsin & 23 & 8 & 3 & -2 & 0 \\
\hline Plains & -3 & 13 & 10 & -8 & 2 \\
\hline Iowa & -29 & 15 & -5 & -27 & -10 \\
\hline Kansas & -10 & -5 & 1 & 6 & -7 \\
\hline Minnesota & 0 & -2 & 5 & 2 & 19 \\
\hline Missouri & 45 & 38 & 24 & -3 & -11 \\
\hline Nebraska & -14 & 20 & 14 & -20 & 7 \\
\hline North Dakota & -153 & -16 & 10 & -14 & 18 \\
\hline South Dakota & -22 & -10 & 11 & -66 & 13 \\
\hline Southeast & -8 & -9 & -8 & -19 & -18 \\
\hline Alabama & -44 & -41 & -32 & -36 & -37 \\
\hline Arkansas & -33 & -8 & -28 & -44 & -21 \\
\hline Florida & 183 & 121 & 124 & 83 & 84 \\
\hline Georgia & -32 & -43 & -33 & -47 & -41 \\
\hline Kentucky & -25 & -31 & -36 & -59 & -45 \\
\hline Louisiana & -201 & -138 & -141 & -120 & -87 \\
\hline Mississippi & -79 & -74 & -55 & -68 & -40 \\
\hline North Carolina & -33 & -34 & -55 & -39 & -64 \\
\hline South Carolina & -17 & -16 & -40 & -48 & -39 \\
\hline Tennessee & -17 & -25 & -19 & -33 & -47 \\
\hline Virginia & 18 & 4 & -15 & -10 & -28 \\
\hline West Virginia & -56 & -34 & -26 & -45 & -38 \\
\hline Southwest & -84 & -46 & -39 & -32 & -39 \\
\hline Arizona & 48 & 37 & 38 & -12 & -28 \\
\hline New Mexico & -101 & -74 & -18 & -86 & -113 \\
\hline Oklahoma & -62 & -36 & -19 & -12 & 2 \\
\hline Texas & -104 & -59 & -56 & -34 & -41 \\
\hline Rocky Mountain & -38 & -15 & -4 & -6 & -7 \\
\hline Colorado & 12 & 16 & 23 & 16 & 15 \\
\hline Idaho & -8 & 18 & 31 & -15 & -19 \\
\hline Montana & -48 & 17 & 53 & 41 & 42 \\
\hline Utah & -52 & -49 & -47 & -36 & -64 \\
\hline Wyoming & -211 & -155 & -151 & -105 & -29 \\
\hline Far West & 26 & -3 & -27 & -7 & -28 \\
\hline Alaska & -298 & -281 & -251 & -132 & -126 \\
\hline California & 42 & 7 & -27 & -8 & -26 \\
\hline Hawaii & 0 & -31 & -61 & -1 & -39 \\
\hline Nevada & -20 & -26 & -17 & -29 & -13 \\
\hline Oregon & 18 & 20 & 21 & -5 & -60 \\
\hline Washington & 36 & 24 & 9 & 23 & -7 \\
\hline
\end{tabular}

\section{Distribution of Creditors and Debtors and Some Trends}

Table 2 presents arithmetic averages of NEA in relation to GSP for selected time periods between 1981 and 2000. Regarding regions, based on the 1981-2000 indicators, New England and the Mideast were the largest creditors, whereas the Southwest and the 
Southeast were the most important debtors. Regarding states, again based on the 1981-2000 indicators, Florida, Vermont, Connecticut, Maine, and Montana were the strongest creditors, while Alaska, Louisiana, Wyoming, New Mexico, and Mississippi were the most important debtors. We observe great disparities in NEA/GSP for U.S. states. If we take a look at the full database of annual observations of NEA/GSP between 1981 and 2000, the 5 cases with the highest indebtedness are Alaska (1981, $-283 \% ; 1982,-345 \% ; 1983,-301 \% ; 1984,-276 \% ; 1985,-281 \%)$. The 5 cases with the strongest creditor position are Florida $(1981,172 \% ; 1982,140 \% ; 1983,147 \%$; $1989,125 \%)$ and Connecticut (1981, $136 \%$ ).

As far as some trends in inter-regional capital movements are concerned, we observe a strong capital inflow into New England (NEA/GSP - in percentage points - declined by 107 between 1981 and 2000) and a relatively important capital outflow from the Southwest (between 1981 and 2000 NEA/GSP grew by 45 in percentage points). Regarding states, the strongest capital inflow is observed for Connecticut (-144), Rhode Island (-134), Delaware (-126), New Hampshire (-122), and Oregon $(-97)$. The most important capital outflow is observed for Wyoming $(+181)$, Alaska $(+157)$, North Dakota $(+120)$, Montana (+93), and Louisiana (+91). Changes in NEA/ GSP (in percentage points) are in parentheses. These are really large numbers. We can infer that physical capital is highly mobile across the states.

Table 2

Arithmetic Averages of Annual Net External Assets in Relation to Gross State Product (in \%) for Regions and States of the United States

\begin{tabular}{|l|c|c|c|c|c|}
\hline Region or state / period & $\mathbf{1 9 8 1 - 8 5}$ & $\mathbf{1 9 8 6 - 9 0}$ & $\mathbf{1 9 9 1 - 9 5}$ & $\mathbf{1 9 9 6 - 2 0 0 0}$ & $\mathbf{1 9 8 1 - 2 0 0 0}$ \\
\hline U.S.A. & 6 & 0 & -4 & -15 & -3 \\
\hline New England & 66 & 27 & 20 & -3 & 28 \\
\hline Connecticut & 96 & 41 & 23 & 1 & 40 \\
\hline Maine & 63 & 44 & 34 & 16 & 39 \\
\hline Massachusetts & 51 & 11 & 12 & -3 & 18 \\
\hline New Hampshire & 58 & 41 & 26 & -31 & 23 \\
\hline Rhode Island & 59 & 24 & 2 & -29 & 14 \\
\hline Vermont & 78 & 53 & 45 & 42 & 54 \\
\hline Mideast & 38 & 16 & 10 & -8 & 14 \\
\hline Delaware & -9 & -54 & -68 & -96 & -57 \\
\hline District of Columbia & 3 & -12 & -26 & -28 & -16 \\
\hline Maryland & 34 & 4 & 6 & 5 & 13 \\
\hline New Jersey & 58 & 23 & 14 & -6 & 22 \\
\hline New York & 28 & 6 & 8 & -12 & 8 \\
\hline Pennsylvania & 52 & 44 & 28 & 1 & 31 \\
\hline Great Lakes & 16 & 7 & 6 & -6 & 6 \\
\hline Illinois & 34 & 16 & 14 & 6 & 18 \\
\hline Indiana & 8 & -8 & -14 & -28 & -10 \\
\hline Michigan & 15 & 21 & 28 & 9 & 18 \\
\hline Ohio & 0 & -8 & -11 & -25 & -11 \\
\hline Wisconsin & 16 & 8 & -2 & -1 & 5 \\
\hline Plains & 14 & 14 & 1 & -2 & 7 \\
\hline Iowa & 13 & 17 & -14 & -16 & 0 \\
\hline
\end{tabular}




\begin{tabular}{|c|c|c|c|c|c|}
\hline Kansas & 1 & 7 & 3 & 1 & 3 \\
\hline Minnesota & 2 & 2 & 4 & 9 & 4 \\
\hline Missouri & 41 & 22 & 9 & -11 & 15 \\
\hline Nebraska & 22 & 30 & -5 & -3 & 11 \\
\hline North Dakota & -46 & 15 & 13 & 9 & -2 \\
\hline South Dakota & 4 & 4 & -28 & -3 & -6 \\
\hline Southeast & -8 & -10 & -14 & -17 & -12 \\
\hline Alabama & -40 & -38 & -30 & -37 & -36 \\
\hline Arkansas & -26 & -17 & -41 & -27 & -28 \\
\hline Florida & 141 & 117 & 97 & 86 & 110 \\
\hline Georgia & -38 & -41 & -43 & -43 & -41 \\
\hline Kentucky & -18 & -36 & -51 & -53 & -40 \\
\hline Louisiana & -160 & -126 & -104 & -90 & -120 \\
\hline Mississippi & -74 & -61 & -65 & -47 & -62 \\
\hline North Carolina & -30 & -51 & -50 & -52 & -46 \\
\hline South Carolina & -19 & -41 & -46 & -43 & -37 \\
\hline Tennessee & -20 & -29 & -32 & -47 & -32 \\
\hline Virginia & 9 & -6 & -15 & -25 & -9 \\
\hline West Virginia & -41 & -34 & -36 & -40 & -38 \\
\hline Southwest & -66 & -24 & -33 & -38 & -40 \\
\hline Arizona & 44 & 33 & 4 & -20 & 15 \\
\hline New Mexico & -104 & -23 & -88 & -96 & -78 \\
\hline Oklahoma & -53 & -8 & -14 & -8 & -21 \\
\hline Texas & -82 & -36 & -38 & -41 & -49 \\
\hline Rocky Mountain & -24 & 0 & -4 & -5 & -9 \\
\hline Colorado & 16 & 22 & 15 & 12 & 17 \\
\hline Idaho & 13 & 27 & 13 & -3 & 12 \\
\hline Montana & -14 & 49 & 50 & 41 & 32 \\
\hline Utah & -51 & -34 & -40 & -51 & -44 \\
\hline Wyoming & -179 & -133 & -116 & -48 & -119 \\
\hline Far West & 7 & -15 & -14 & -19 & -10 \\
\hline Alaska & -297 & -222 & -141 & -125 & -196 \\
\hline California & 22 & -12 & -14 & -18 & -6 \\
\hline Hawaii & -23 & -46 & -27 & -29 & -31 \\
\hline Nevada & -26 & -32 & -30 & -16 & -26 \\
\hline Oregon & 29 & 20 & 8 & -39 & 4 \\
\hline Washington & 25 & 13 & 13 & 5 & 14 \\
\hline
\end{tabular}

The database of NEA/GSP shows relatively important dispersions of NEA among the states. The given database can be used in future research. For example, Duczynski and Tóthová (2002) show that rich U.S. states have a tendency to be net debtors, whereas in international comparisons rich countries are on average net creditors. The growth of NEA (the capital outflow) is negatively correlated with the product growth among U.S. states, while the given correlation is positive among countries. This is a certain indication that international capital flows may have been inefficient (a capital inflow was connected with slow product growth). It is likely that the capital flows across U.S. states were more efficient than international capital flows. 
We should also note that the present contribution analyses positions of the private sector in states and regions. In other words, we abstract from the positions of local governments. Fiscal positions of U.S. states are, for example, discussed in Bayoumi et al. (1995).

\section{Correlation Matrices and the Degree of Capital Mobility}

To learn more about the degree of capital mobility among the U.S. states, we present correlation coefficients of NEA/GSP for selected base years in Table 3. If capital were completely immobile, these coefficients would be equal to 1 (or very close to 1). Except for the diagonal elements, correlation coefficients fall short of 1, so capital is likely to be highly mobile. Nevertheless, since these coefficients are always positive, we observe some persistency in NEA/GSP across the states. Qualitatively similar results are obtained if we consider the correlation matrix for regions (Table 4). Many of the correlation coefficients are substantially below 1, so capital was likely to be highly mobile across the regions. We can also consider selected correlation matrices for shorter time periods (Tables 5-8). We focus on the initial and the final years of the period 1980-2000, so that we may assess the change in capital mobility. The results differ. Correlation coefficients in Tables 5 and 6 are close to 1, while many correlation coefficients in Tables 7 and 8 are substantially below 1. It is therefore possible that the degree of inter-state or inter-regional capital mobility increased from the early $1980 \mathrm{~s}$ to the late 1990s.

Table 3

The Correlation Matrix for NEA/GSP and 51 U.S. States in Selected Base Years

\begin{tabular}{|l|c|c|c|c|c|}
\hline \multicolumn{1}{|c|}{ Years } & $\mathbf{1 9 8 0}$ & $\mathbf{1 9 8 5}$ & $\mathbf{1 9 9 0}$ & $\mathbf{1 9 9 5}$ & $\mathbf{2 0 0 0}$ \\
\hline $\mathbf{1 9 8 0}$ & 1.00 & 0.92 & 0.82 & 0.82 & 0.48 \\
\hline $\mathbf{1 9 8 5}$ & 0.92 & 1.00 & 0.95 & 0.88 & 0.66 \\
\hline $\mathbf{1 9 9 0}$ & 0.82 & 0.95 & 1.00 & 0.86 & 0.70 \\
\hline $\mathbf{1 9 9 5}$ & 0.82 & 0.88 & 0.86 & 1.00 & 0.74 \\
\hline $\mathbf{2 0 0 0}$ & 0.48 & 0.66 & 0.70 & 0.74 & 1.00 \\
\hline
\end{tabular}

Table 4

The Correlation Matrix for NEA/GSP and 8 Regions in Selected Base Years

\begin{tabular}{|l|l|l|l|l|l|}
\hline \multicolumn{1}{|c|}{ Years } & $\mathbf{1 9 8 0}$ & $\mathbf{1 9 8 5}$ & $\mathbf{1 9 9 0}$ & $\mathbf{1 9 9 5}$ & $\mathbf{2 0 0 0}$ \\
\hline $\mathbf{1 9 8 0}$ & 1.00 & 0.95 & 0.75 & 0.92 & 0.32 \\
\hline $\mathbf{1 9 8 5}$ & 0.95 & 1.00 & 0.89 & 0.93 & 0.55 \\
\hline $\mathbf{1 9 9 0}$ & 0.75 & 0.89 & 1.00 & 0.85 & 0.76 \\
\hline $\mathbf{1 9 9 5}$ & 0.92 & 0.93 & 0.85 & 1.00 & 0.48 \\
\hline $\mathbf{2 0 0 0}$ & 0.32 & 0.55 & 0.76 & 0.48 & 1.00 \\
\hline
\end{tabular}


Table 5

The Correlation Matrix for NEA/GSP and 51 U.S. States in Shorter Periods

\begin{tabular}{|l|c|c|c|c|c|c|}
\hline \multicolumn{1}{|c|}{ Years } & $\mathbf{1 9 8 0}$ & $\mathbf{1 9 8 1}$ & $\mathbf{1 9 8 2}$ & $\mathbf{1 9 8 3}$ & $\mathbf{1 9 8 4}$ & $\mathbf{1 9 8 5}$ \\
\hline $\mathbf{1 9 8 0}$ & 1.00 & 0.99 & 0.95 & 0.94 & 0.95 & 0.92 \\
\hline $\mathbf{1 9 8 1}$ & 0.99 & 1.00 & 0.98 & 0.97 & 0.97 & 0.94 \\
\hline $\mathbf{1 9 8 2}$ & 0.95 & 0.98 & 1.00 & 0.98 & 0.98 & 0.97 \\
\hline $\mathbf{1 9 8 3}$ & 0.94 & 0.97 & 0.98 & 1.00 & 0.99 & 0.98 \\
\hline $\mathbf{1 9 8 4}$ & 0.95 & 0.97 & 0.98 & 0.99 & 1.00 & 0.99 \\
\hline $\mathbf{1 9 8 5}$ & 0.92 & 0.94 & 0.97 & 0.98 & 0.99 & 1.00 \\
\hline
\end{tabular}

Table 6

The Correlation Matrix for NEA/GSP and 8 Regions in Shorter Periods

\begin{tabular}{|l|l|l|l|l|l|l|}
\hline \multicolumn{1}{|c|}{ Years } & $\mathbf{1 9 8 0}$ & $\mathbf{1 9 8 1}$ & $\mathbf{1 9 8 2}$ & $\mathbf{1 9 8 3}$ & $\mathbf{1 9 8 4}$ & $\mathbf{1 9 8 5}$ \\
\hline $\mathbf{1 9 8 0}$ & 1.00 & 0.99 & 0.97 & 0.97 & 0.99 & 0.95 \\
\hline $\mathbf{1 9 8 1}$ & 0.99 & 1.00 & 0.99 & 0.99 & 0.99 & 0.97 \\
\hline $\mathbf{1 9 8 2}$ & 0.97 & 0.99 & 1.00 & 0.99 & 0.99 & 0.99 \\
\hline $\mathbf{1 9 8 3}$ & 0.97 & 0.99 & 0.99 & 1.00 & 1.00 & 0.99 \\
\hline $\mathbf{1 9 8 4}$ & 0.99 & 0.99 & 0.99 & 1.00 & 1.00 & 0.99 \\
\hline $\mathbf{1 9 8 5}$ & 0.95 & 0.97 & 0.99 & 0.99 & 0.99 & 1.00 \\
\hline
\end{tabular}

Table 7

The Correlation Matrix for NEA/GSP and 51 U.S. States in Shorter Periods

\begin{tabular}{|l|l|l|l|l|l|l|}
\hline \multicolumn{1}{|c|}{ Years } & $\mathbf{1 9 9 5}$ & $\mathbf{1 9 9 6}$ & $\mathbf{1 9 9 7}$ & $\mathbf{1 9 9 8}$ & $\mathbf{1 9 9 9}$ & $\mathbf{2 0 0 0}$ \\
\hline $\mathbf{1 9 9 5}$ & 1.00 & 0.99 & 0.94 & 0.72 & 0.67 & 0.74 \\
\hline $\mathbf{1 9 9 6}$ & 0.99 & 1.00 & 0.94 & 0.72 & 0.67 & 0.74 \\
\hline $\mathbf{1 9 9 7}$ & 0.94 & 0.94 & 1.00 & 0.83 & 0.79 & 0.86 \\
\hline $\mathbf{1 9 9 8}$ & 0.72 & 0.72 & 0.83 & 1.00 & 0.98 & 0.96 \\
\hline $\mathbf{1 9 9 9}$ & 0.67 & 0.67 & 0.79 & 0.98 & 1.00 & 0.97 \\
\hline $\mathbf{2 0 0 0}$ & 0.74 & 0.74 & 0.86 & 0.96 & 0.97 & 1.00 \\
\hline
\end{tabular}

Table 8

The Correlation Matrix for NEA/GSP and 8 Regions in Shorter Periods

\begin{tabular}{|l|l|l|l|l|l|l|}
\hline \multicolumn{1}{|c|}{ Years } & $\mathbf{1 9 9 5}$ & $\mathbf{1 9 9 6}$ & $\mathbf{1 9 9 7}$ & $\mathbf{1 9 9 8}$ & $\mathbf{1 9 9 9}$ & $\mathbf{2 0 0 0}$ \\
\hline $\mathbf{1 9 9 5}$ & 1.00 & 0.99 & 0.98 & 0.32 & 0.31 & 0.48 \\
\hline $\mathbf{1 9 9 6}$ & 0.99 & 1.00 & 0.98 & 0.32 & 0.30 & 0.49 \\
\hline $\mathbf{1 9 9 7}$ & 0.98 & 0.98 & 1.00 & 0.42 & 0.41 & 0.56 \\
\hline $\mathbf{1 9 9 8}$ & 0.32 & 0.32 & 0.42 & 1.00 & 0.99 & 0.95 \\
\hline $\mathbf{1 9 9 9}$ & 0.31 & 0.30 & 0.41 & 0.99 & 1.00 & 0.95 \\
\hline $\mathbf{2 0 0 0}$ & 0.48 & 0.49 & 0.56 & 0.95 & 0.95 & 1.00 \\
\hline
\end{tabular}




\section{The Regional Current Account}

From the data on NEA/GSP, we can derive at least very rough estimates of the currentaccount ratios (CA/GSP) for regions and states. CA/GSP can be approximated by the difference of NEA/GSP between two subsequent years. In this way we computed CA ratios for the time intervals 1980-81, 1985-86, 1990-91, 1995-96, and 2000-2001. The degree of international (inter-regional) capital mobility can be approximated by the absolute value of the CA ratio. For the given time intervals, we computed arithmetic averages of absolute values of CA/GSP for states and regions. For 1980-81, we obtained $9.1 \%$ for states, $3.9 \%$ for regions, and $2 \%$ for the United States as a whole. For $1985-86$, we got $16.5 \%$ for states, $10.5 \%$ for regions, and $0 \%$ for the United States. For $1990-91$, we received $8.2 \%$ for states, $3.5 \%$ for regions, and $1 \%$ for the United States. For $1995-96$, we got $4.8 \%$ for states, $2.3 \%$ for regions, and $1 \%$ for the United States. For 2000-2001, we obtained 10.8\% for states, 7.9\% for regions, and $4 \%$ for the U.S.A. Therefore, capital mobility tends to be higher for smaller economies - higher for states, lower for regions and the lowest for the U.S.A. as a whole. In economics we know that smaller economies have a tendency to be more open on average than larger economies. The present evidence supports this view.

\section{6. $\sigma$-convergence and $\beta$-convergence}

If the standard deviation of a variable in a sample decreases over time, we have $\sigma$-convergence. If the growth of a variable depends significantly negatively on the initial level of the given variable, we have $\beta$-convergence. It is well known in economics that $\sigma$-convergence implies $\beta$-convergence, while the opposite is not the case (see Barro and Sala-i-Martin, 1995). Barro and Sala-i-Martin (1991) examine the convergence of SPI and GSP among U.S. states. Here we follow this approach, focusing on NEA instead.

For 1980 , the average NEA/GSP is $-5.9 \%$ for states and $9.0 \%$ for regions. Standard deviations are $84.8 \%$ for states and $55.6 \%$ for regions. For 1985 , the average NEA/GSP is $-8.7 \%$ for states and $1.6 \%$ for regions. Standard deviations are $61.5 \%$ for states and $26.6 \%$ for regions. For 1990 , the average is $-10.5 \%$ for states and $-2.0 \%$ for regions. Standard deviations of NEA/GSP are $57.5 \%$ for states and $22.0 \%$ for regions. For 1995 , the average is $-17.6 \%$ for states and $-5.1 \%$ for regions. Standard deviations are $41.5 \%$ for states and $16.0 \%$ for regions. For 2000 , the average NEA/GSP is $-23.7 \%$ for states and $-16.0 \%$ for regions. Standard deviations are $38.5 \%$ for states and $12.9 \%$ for regions. Since the arithmetic averages of NEA/GSP decline over time both for regions and states, we observe an average tendency towards capital inflows into regions and states. This is consistent with the fact that the United States as a whole were a net capital importer. Since the standard deviations uniformly and substantially decline over time, we have evidence for $\sigma$-convergence of NEA/GSP between 1980 and 2000.

To examine $\beta$-convergence, we regressed (using ordinary least squares) the change in NEA/GSP between 1980 and 2000 on the initial level of NEA/GSP:

$$
\begin{aligned}
\Delta(\mathrm{NEA} / \mathrm{GSP})=(\mathrm{NEA} / \mathrm{GSP})_{2000}-(\mathrm{NEA} / \mathrm{GSP})_{1980}=-22.4 \%-0.781(\mathrm{NEA} / \mathrm{GSP})_{1980} \\
(-4.68)(-13.76)
\end{aligned}
$$


The value of $\mathrm{R}^{2}$ is 0.79 , and t-statistics are in parentheses. Since this dependence is negative and strongly significant, we have good evidence for $\beta$-convergence, consistently with the fact that $\sigma$-convergence implies $\beta$-convergence. Figure 1 shows the dependence of $(\mathrm{NEA} / \mathrm{GSP})_{2000}$ on (NEA/GSP) ${ }_{1980}$. This dependence is positive. Figure 2 presents the dependence of $\Delta(\mathrm{NEA} / \mathrm{GSP})$ on $(\mathrm{NEA} / \mathrm{GSP})_{1980}$. This dependence is negative.

\section{Conclusion}

Using the data on gross state product (GSP) and state personal income (SPI), we constructed rough estimates of net external assets (NEA) for 8 regions and 51 states of the United States. The present paper shows some of these data in 1980-2000. A full database of annual observations of NEA relative to GSP for the 1977-2001 period is available at the Internet address http://duczynski.czweb.org. We identified the largest creditors and debtors and some trends in capital movements across the regions and states. Correlation coefficients of NEA/GSP in two different years were proposed as a measure of capital mobility among regions or states. We were able to construct at least very rough estimates of the regional current account and infer that capital mobility was on average higher for states (smaller economies) than for regions. We also provided evidence for the $\sigma$-convergence and $\beta$-convergence of NEA between 1980 and 2000. Future research could use the given database of NEA and could extend it for more recent years. Alternatively, future research could focus on capital movements among other regional economies, such as Canadian provinces, Japanese prefectures, or Western European regions.

\section{References}

Barro, R. J., Sala-i-Martin, X. (1991), "Convergence across States and Regions." Brookings Papers on Economic Activity, 1, pp. 107-182.

Barro, R. J., Sala-i-Martin, X. (1995), Economic Growth. New York: McGraw-Hill.

Bayoumi, T., Goldstein, M., Woglom, G. (1995), "Do Credit Markets Discipline Sovereign Borrowers? Evidence from U.S. States.” Journal of Money, Credit, and Banking, 27(4), pp. 1046-1059.

Duczynski, P. (2000), "Capital Mobility in Neoclassical Models of Growth: Comment." American Economic Review, 90(3), pp. 687-694.

Duczynski, P., Tóthová, A. (2002), "On the Statics and Dynamics of Net External Assets." mimeo, CERGE-EI, Prague, Czech Republic.

International Monetary Fund (various issues), International Financial Statistics, Washington, DC.

Kalemli-Ozcan, S., Sorensen, B. E., Reshef, A., Yosha, O. (2005), "Why Does Capital Flow to Rich States?" Working Paper 2005-04, Department of Economics, University of Houston.

Lane, P. R., Milesi-Ferretti, G. M. (2001), "The External Wealth of Nations: Measures of Foreign Assets and Liabilities for Industrial and Developing Countries." Journal of International Economics, 55(2), pp. 263-294.

Sinn, S., 1990, Net External Asset Positions of 145 Countries: Estimation and Interpretation, Kieler Studien 234, Tübingen: Mohr.

Survey of Current Business, U.S. Department of Commerce, Bureau of Economic Analysis, various issues. 


\section{Appendix:}

Figure 1

The dependence of Net External Assets in 2000 on Net External Assets in 1980 for 51 U.S. States

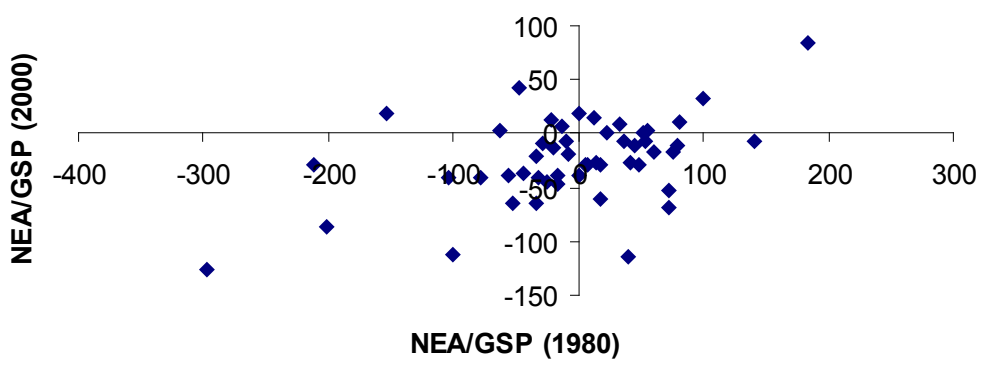

Figure 2

The Dependence of the Change in Net External Assets betveen 1980 and 2000 on the Initial Value

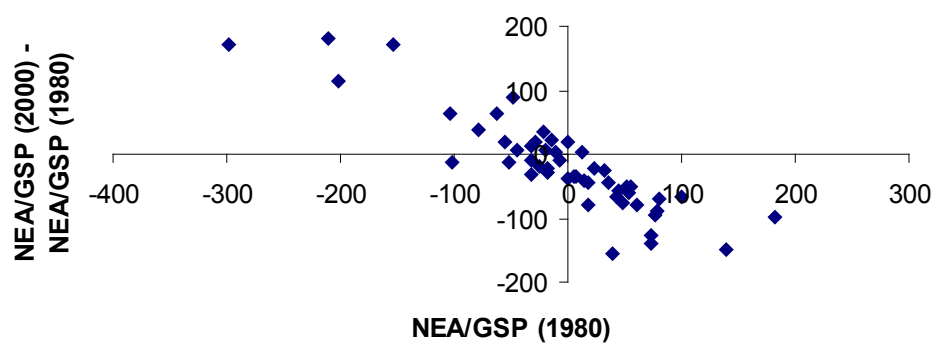

